\title{
SOCIALIST EDUCATIONAL POLICY IN THE AUTONOMOUS REGION OF KOSOVO AND METOHIJA Goals, Objectives, and Outcomes
}

\begin{abstract}
This research aims to shed light on the social challenges of school development in Kosovo and Metohija after the Second World War. It examines how the philosophy created in Soviet Union and Western Marxist circles was applied in nationally divided, predominantly agrarian, traditional society, with an extremely high illiteracy rate. The paper also shows how society is impacted when educational policy in a certain area becomes a means for achieving ideological goals. The study is grounded in the unpublished documents of the Archives of Yugoslavia, Archives of Serbia, and the Central State Archives of Albania.
\end{abstract}

KeYWORDS: Socialist education; Kosovo and Metohija; Yugoslavia; Josip Broz; Univeristy of Priština.

1 vukadinovicigor3@gmail.com

Рад је примљен 25. октобра 2021, а прихваћен за објављивање на састанку Редакције 3борника одржаном 21. децембра 2021. 
INTRODUCTION

The area of Kosovo and Metohija was one of the regions with the least developed education, not only in Yugoslavia but also in Europe. According to the 1921 census, illiteracy was as high as 95.6 per cent. Ten years later, in the 1931 census, illiteracy was reduced to 84.2 per cent (Slavković, 2018, pp. 323-325). In the Kingdom of Yugoslavia, education started by attending a four-year elementary school for children between the ages of seven and eleven, followed by four years of 'lower secondary school' and then four years of 'higher secondary school'. The authorities of the Kingdom of Yugoslavia believed that all school-age children should be brought up in the spirit of loyalty to the state, the king, the dynasty, and the culture of the majority people (Hrabak, p. 303-304). Albanian and Turkish students in public schools attended classes in Serbian, while they could attend Islamic and Catholic religious schools in their mother tongue (Slavković, 2018, pp. 495-498, Dimić, 1990, pp. 194-196).

After the occupation of Yugoslavia in 1941, the territory of Kosovo and Metohija was assigned to the Italian protectorate of the 'Kingdom of Albania', which soon implemented the measures for the development of Albanian education in the annexed territories. Two hundred teachers from Albania were sent to Kosovo with the task of improving the level of education and strengthening the Albanian national idea. In addition to opening primary schools, second-level schools in Albanian were established in Priština, Prizren, Peć, Đakovica, Uroševac and Gnjilane (Fetahu, Çunaku, 2011, pp. 67; Vukadinović, 2020, pp. 116-118). ${ }^{2}$

At the end of the Second World War, the Communist Party came to power in Yugoslavia, which led to major changes in the political, economic, and educational organisation of the state. Yugoslavia became a federal state, composed of six republics. The largest republic, Serbia, formed two autonomous regions-Autonomous Province of Vojvodina and Autonomous Region of Kosovo and Metohija. $^{3}$ Since the economic situation of the country was extremely difficult, the communists intended to show the 'progres-

See: Arkivi Qendror Shtetëror [Central state archives of Albania] (AQSH), fondi 178, Ministria e Financave, Drejtoria e Pergjithshme e Financave [Ministry of Finance, General Directorate of Finance], viti (v.) 1941, d. I-2636, njësia arkivorë [archival unit] (n.a.) 2, 'Rregullimi dhe administrimi i shkollave të mesme në Kosovë e Dibër', November 12, 1941. 
sive' character of the new government in the sphere of education. Kosovo and Metohija, as a multinational autonomous region, with an extremely low literacy rate, provided a suitable ground for this policy. The idea was to integrate this region into modern socialist society through courses on the elimination of illiteracy, the introduction of Marxist education and the promotion of the values of 'brotherhood and unity' (Miladinović, 1977, pp. 22-41). ${ }^{4}$ In addition to the propaganda motive, the education of professional staff and workers was a necessary precondition for the accelerated industrialisation that Communists intended to implement (Craig, 1981, p. 151).

In 1958, The Commission for National Minorities of the League of Communists of Yugoslavia concluded that, during the post-war period investment in the development of educational institutions in Kosovo and Metohija was prioritised over investment in the economy of that area. The Commission noted that prevailing opinion at the end of the war was that the issue of integration of the Albanian national minority in Yugoslavia could be resolved in the 'Marxist spirit' by educating young people. ${ }^{5}$

ESTABLISHMENT OF MASS EDUCATION IN THE ALBANIAN LANGUAGE

The problem of education in this area was opened immediately after its liberation, while war operations were still going on in other parts of Yugoslavia. Power in Kosovo and Metohija was assigned to the Regional Committee of the Communist Party of Yugoslavia for Kosovo and Metohija and the Presidency of the Regional People's Liberation Council of Kosovo and Metohija. ${ }^{6}$ The Albanian communists Fadil Hoxha, Xhavid Nimani and Zekeria Rexha, who were employed in the educational system of the

3 As a result of constitutional changes in 1963, the Autonomous Region of Kosovo and Metohija was transformed into 'Autonomous Province of Kosovo and Metohija'.

4 Arhiv Jugoslavije [Archives of Yugoslavia] (hereafter AJ), fond 507, Centralni komitet Saveza komunista Jugoslavije [Archive group of the Central Committee of the League of Communists of Yugoslavia] (507), XVIII, Komisija za nacionalne manjine [Commission for National Minorities] (XVIII)-K.4/11, 'Deo izveštaja o albanskoj nacionalnoj manjini', 1957.

5 AJ, 507, XVIII-K.11/15, 'Deo izveštaja o albanskoj nacionalnoj manjini', 1957.

6 People's Liberation Council later became People's Assembly of Kosovo and Metohija, while it's Presidency was renamed in Executive Council of Autonomous Region of Kosovo and Metohija. 
'Kingdom of Albania' during 1941, had a great influence in these bodies. One of the first departments formed by the Executive Council of Kosovo and Metohija was the Department of Education, which began operating in December 1944. The Executive Council Secretary, Pavle Jovićević, reported that seeking teachers for schools was one of the new government's priorities, which is why it was decided to remove all soldiers with teaching qualifications from the army and hire them in schools (Narodni odbor Autonomne kosovsko-metohjske oblasti 1943-1953, 1955, p. 28).

Another important decision was to keep all teachers who had worked during the occupation within the educational system of the fascist 'Kingdom of Albania'. Since the Communists took power in both Yugoslavia and Albania in 1944, in line with the philosophy of proletarian internationalism the two countries formed extremely close relations and intense cooperation. Belgrade allowed Albanian teachers, who had been relocated from Albania to Kosovo during the occupation, to remain at work because of a lack of educational staff. 7

A dispute soon arose between the Yugoslav Ministry of Foreign Affairs and the Kosovo and Metohija Regional Executive Council over this issue. In the spring of 1945, the representative of the Albanians from Kosovo, Fadil Hoxha, spoke with the Albanian leader Enver Hoxha in Tirana about bringing new educators from Albania to Kosovo and Metohija. The Kosovo and Metohija Regional People's Liberation Council officially requested that the Government of Yugoslavia permit the arrival of new Albanian educators in Kosovo. ${ }^{8}$ On the other hand, the Yugoslav Ministry of Foreign Affairs opposed this initiative, believing that in principle, the admission of foreign nationals to the Yugoslav civil service cannot be allowed'. 9 Under pressure from the party leadership, the Ministry of Foreign

7 Yugoslav authorities tried to determine which of these teachers were fervent supporters of fascist ideology, in order to remove them from teaching. See: AQSH, f. 511, Ministria e Arsimit dhe Kulturës [Ministry of Education and Culture], v. 1945, d. 35, 'Qarkore e Ministrisë së Arsimit dërguar seksioneve të arsimit të prefekturave të ndryshme mbi dërgimin nga ana e tyre të listave të arsimtarëve që japin mësim në Kosovë', n.a. 3-6.

8 Diplomatski arhiv ministarstva spoljnih poslova [Diplomatic archive of the Ministry of Foreign Affairs of Serbia] (DAMSP), Politička arhiva (PA) [Political archive] - 1945, Albanija, f. 1, dosije (d.) 9, 'Dopis Narodnooslobodilačkog odbora KiM Nacionalnom komitetu OJ - povereništvu za prosvetu', March 2, 1945.

9 DAMSP, PA-1945, Albanija, f. 1, d. 9, 'Dopis Narodnooslobodilačkog odbora KiM Nacionalnom komitetu OJ - povereništvu za prosvetu', 2 Mar. 1945. 
Affairs soon had to give up its position, so new contingents of teachers from Albania were sent to Yugoslavia. ${ }^{10}$ During the 1945/1946 school year 354 Albanian educators were employed in Kosovo and Metohija, most of whom were part of the educational system of the Kingdom of Albania from 1941 to $1944 . .^{11}$

Education was the subject of conversation between the delegation of Albanians from Kosovo and Josip Broz Tito on April 6, 1945. The Communist Party leader promised the state aid in the development of education in that area. ${ }^{12}$ The law mandating compulsory seven-year education was passed in October 1945, which meant that all Yugoslav children between the ages of 7 and 13 were required to attend school. The Act on the Education of National Minorities in Yugoslavia was also passed in 1945 and stipulated the establishment of minority schools in all areas inhabited by national minorities. Classes at these schools were taught in the minority's mother tongue. The language of the Yugoslav republic in which the national minority stayed was taught for three school hours per week. ${ }^{13}$

In the 1946 Budget, the Regional People's Council distributed most of the money to the Department of Education. The issue of education was closely monitored and discussed at each regular session of the Regional People's Council during the first decade of the post-war era (Narodni odbor Autonomne kosovsko-metohjske oblasti 1943-1953, 1955, p. 99. At the Fifth Party Congress in 1948, high-ranking state official Aleksandar Ranković described Kosovo and Metohija as the area with the highest percentage of uneducated people among party members (V kongres Komunističke partije Jugoslavije. Izveštaji i referati, 1948, p. 217). ${ }^{14}$ At the same congress, it was

10 AJ, 315, Komitet za škole i nauku pri vladi FNRJ [Committee for Schools and Science under the Government of the Federal People's Republic of Yugoslavia], f. 3, arhivska jedinica [archival unit] (a.j.) 883, 'Poslanstvo NR Albanije Ministarstvu inostranih poslova FNRJ', 26 Mar. 1947.

11 AJ, 507, XVIII-K.4/21, 'Informacija o neprijateljskoj propaganda iz Albanije i stanju Albanaca u Jugoslaviji', Jan. 1960.

12 AJ, 97, Komisija za agrarnu reform i kolonizaciju pri Vladi FNRJ [Commission for Agrarian Reform and Colonisation of the Government of the Federal People's Republic of Yugoslavia], f. 4, a.j. 44, 'Delegacija Albanaca sa Kosova i Metohije posetila je maršala Tita', April 6, 1945, 2-3.

13 AJ, 507, XVIII-K.9/12. 'Osnovne karakteristike ostvarnog kulturno-prosvetnog života i rada nacionalnih manjina u Srbiji. Manjinsko školstvo', 1958.

14 As many as 28.2 per cent of the party members in Kosovo and Metohija did not have a school, and the issue was also expressed in Bosnia and Herzegovina, where 21.72 per cent of the party members were uneducated. 
concluded that the building of socialism was inextricably linked to cultural and scientific development, which also meant the liquidation of the ideological remnants of capitalism (Petrović-Todosijević, 2016, pp. 39-42).

The number of students in Kosovo and Metohija was growing steadily in the first two post-war decades. The regional leadership saw the expansion of education as a priority political issue. At the session of the People's Council of Kosovo and Metohija on 25 August 1952, high regional official Mehmet Hoxha said: 'Even the greatest pessimists must admit that the people's government has achieved great success in terms of education in our area' (Narodni odbor AKMO 1943-1953, 1955, p. 754; Nikolić, 1963, p. 43). In the school year 1945/ 46 there were 388 primary schools in Kosovo and Metohija, which were attended by 50,747 students. Over the next eleven years the number of students more than doubled, so that there were 122,091 students in the region during the school year 1956/1957, of whom 64 per cent attended classes in Albanian and 33 per cent in Serbian. ${ }^{15}$

Following the split between Tito and Stalin in 1948, the Yugoslav authorities shifted from copying Soviet solutions in the economy and culture to challenging them. The aim was to establish a 'unique Yugoslav path to socialism', which was also reflected in educational policy. Educational experts had been working for years to establish an innovative Yugoslav education system. The lack of competent teaching staff was a major impediment to the implementation of these plans. According to a 1948 report by the Ministry of Education of Serbia, this problem was especially severe in Albanian schools: 'Among the unqualified teachers in primary schools, there are many who have only primary school, those with a completed madrasa or with some grade of grammar school'. ${ }^{16}$ Out of the 385 teachers who taught in Albanian schools in the 1947/48 school year, 235 did not have the required qualifications.

There were numerous cases recorded that demonstrate how the issue of incompetent teachers impacted the daily teaching process. In one school in Orahovac, the subject French was taught by a teacher who publicly admitted that he doesn't speak that language. ${ }^{17}$ In the same school, the Serbian language was taught by an Albanian who did not know Serbian well. Some geography teachers

15 AJ, 319, f. 31, 'Analiza društvenog plana SAP Kosova 1965-1970', March, 1970, 6-7.

16 AJ, 315, f. 11, 'Ministarstvo prosvete Srbije Komitetu za škole i nauku FNRJ', March 27, 1948.

17 AS, BIA, III-136, 'Stanje albanskog prosvetnog kadra na terenu AKMO', 1962, 13. 
taught children that Yugoslavia borders Russia. ${ }^{18}$ Even after completing four years of primary school, part of the students remained illiterate, suggesting a low level of primary education quality. ${ }^{19}$ State official Xhavid Nimani spoke about this problem at the session of the Regional People's Council in 1952:

Our education course so far has been aimed at opening as many schools as possible and at constantly increasing the number of educators. However, little attention was paid to the quality of work in schools and the expertise of the teaching staff, and this is one of the main shortcomings in our work in the field of education (Narodni odbor Autonomne kosovsko-metohjske oblasti 1943-1953, 1953, p. 753).20

A 1958 report by the party's Commission for National Minorities states that 'self-taught, almost illiterate people' were appointed as teachers in Kosovo and Metohija schools after the war. ${ }^{21}$ Unqualified teachers made up for the lack of education through vocational courses in Prizren and Priština. Further training of teachers soon began to be done through special classes at teacher training schools. Unqualified teachers who attended these schools had double duties: they served in the school throughout the day and listened to the teacher's school lessons in the evening. In addition, they were preparing to take the subject during the summer. ${ }^{22}$

The accelerated development of primary and secondary education and the permanent increase in the number of students also demanded an increase in the number of teaching staff, which resulted a very slow eradication of unqualified education among teachers. According to the authorities' data, in 1959 there was no school in Kosovo and Metohija in which all teachers were qualified. ${ }^{23}$

18 Ibid.

19 AJ, 318, f. 94, a.j. 127, 'Osnovno obrazovanje odraslih', 1963, 9.

20 Original quotation: 'Naš dosadašnji kurs prosvete bio je usmeren na otvaranje što većeg broja škola i na stalno povećanje broja prosvetnih radnika. Međutim, o kvalitetu rada u školama i o stručnosti i uzdignutosti prosvetnog kadra manje se vodilo računa, i to je jedan od glavnih nedostataka u našem radu na području prosvete'.

21 AJ, 507, XVIII-K.7/3, 'Informacija o problemima školstva kod nacionalnih manjina', 1958 .

22 AJ, 318, f. 94, a.j. 127, 'Vanškolski oblici obrazovanja odraslih u AKMO', 1963, 67; AJ, 507, XVIII-K.9/22, 'Amaterske i profesionalne kulturno-prosvetne ustanove, kulturno-prosvetni problem nacionalnih manjina', 1959, 6.

23 AJ, 507, XVIII-K.9/22, 'Amaterske i profesionalne kulturno-prosvetne ustanove, kulturno-prosvetni problem nacionalnih manjina', 1959, 5. 
One of the first major actions taken by the Yugoslav communists was a campaign to 'enlighten' the people and suppress illiteracy among the adult population. It was also an important aspect of the post-war propaganda of the Communist Party of Yugoslavia, which was supposed to show the progressive character of the regime (Gatalović, 2009, pp. 38-39; Doknić, 2013, pp. 40-51). Like other moves by the Yugoslav communist government, the eradication of illiteracy was based on the copying of the Soviet model to solve this problem in the 1920s. As the number of educators in the entire country was insufficient, all individuals who had necessary skills for the job were involved in the literacy action. Literacy courses were held under the auspices of mass organisations led by the communist movement-the Popular Front, the Anti-Fascist Women's Council, the United Socialist Anti-Fascist Youth, trade unions and cooperatives (Gudac-Dodić, 2006, pp. 90-94). ${ }^{24}$ The Day of Struggle for the Suppression of Illiteracy was also established, for which the day of Lenin's birth was chosen (Bondžić, 2010, p. 95).

At the end of 1945, the government formed special commissions for public education, which had the task of directing the work on the suppression of illiteracy, coordinating state bodies and mass organisations, and materially supplying the courses. ${ }^{25}$ Literacy courses faced various problems of material and professional nature. They were most often held during the winter and spring months, in insufficient spatial conditions. Many participants, due to home and business obligations, did not manage to attend the courses regularly, and some viewed participation in them as a form of coercion. Most of the 11,000 managers of illiteracy courses in Serbia did not have academic skills for this job, which was reflected in the quality of the courses. These courses usually lasted three months instead of the planned five (Dimić, 1988, pp. 131-132). According to official statistics, the pass rate at the final exam was 67 per cent. It also happened that the participants of the courses soon forgot what they had learned (Dobrivojević, 2011, p. 161).

24 AJ, 313, Ministarstvo prosvete Vlade FNRJ [Ministry of Education of Yugoslavia], f. 3, a.j. 220, 'Uputstva za rad na suzbijanju nepismenosti na teritoriji Srbije, Vojvodine, Kosova i Metohije', 8 Dec. 1945.

25 AJ, 313, f. 3, a.j. 220, 'Uputstva za rad na suzbijanju nepismenosti na teritoriji Srbije, Vojvodine, Kosova i Metohije', 8. Dec. 1945. 
Literacy courses were used to reinforce the new regime. The first sentences that the participants learned to compose were dedicated to the glorification of communism and 'Comrade Tito'. Letters from participants who thanked the Yugoslav leadership and Tito for learning to read and write were published regularly in the press. The lecturers underwent fifteen days of "political-pedagogical training" in order to be put into the service of the ruling ideology (Bondžić, 2010, pp. 99-100). According to the official data of the Communist party from 1959, about 260.000 people had passed through illiteracy courses in Kosovo and Metohija by then, of which 182,000 were Albanians. According to the same document, about 200,000 people became literate between 1945 and 1950, while another 60,000 people became literate from 1951 to 1959. It was also stated that 'in recent years, these institutions have almost stopped working'. ${ }^{26}$

During the 1950s, functional literacy in the form of reading and writing was no longer considered a sufficient level of education. Therefore, illiteracy courses began to be regarded as an outdated method, which was no longer able to meet new standards in social and economic development. New forms of adult education were introduced, such as two-year schools for primary adult education and 'worker gymnasiums. Through these institutions, adults acquired a complete primary education, covering the curriculum from the first to the eighth grade. These schools, organised by worker universities and school councils, were considered a more expensive and complicated form of adult education, but with better and more lasting results. ${ }^{27}$ By 1962 , nine school centers for primary adult education had been established in the Region. They were mostly attended by employees who were required to have completed primary school as a condition for remaining on the job. ${ }^{28}$ Attendance at adult schools intensified after the adoption of the Resolution on the education of professional staff in the Federal National Assembly in June 1960. Classes were held by teachers from regular primary schools, who thus supplemented the work norm or worked as part-time employees. ${ }^{29}$

26 AJ, 507, XVIII-K.9/22, 'Amaterske i profesionalne kulturno-prosvetne ustanove', 1959.

27 Ibid.

28 AJ, 318, Savezni sekretarijat za obrazovanje i kulturu [Federal Secretariat for Education and Culture], f. 94, a.j. 127, 'Vanškolski oblici obrazovanja odraslih u AKMO', 1963. 
Women's illiteracy was especially pronounced in the region - it was as high as 98.5 per cent in the 1921 census and slightly decreased to 93.9 per cent 10 years later (Slavković, 2018, p. 323). Extremely high illiteracy rate among women stemmed from the patriarchal character of the society of that time and the understanding that men and women had demarcated roles in marriage and family. Childbirth, child care, and household care were regarded as the role of women in marriage, while education and intellectual uplift were generally regarded as a 'male work'. This understanding was retained in some rural Serbian areas during the socialist period..$^{30}$ By 1971, illiteracy among women in Kosovo and Metohija was reduced to 43.5 per cent, while among men it was 21.3 per cent (Islami, 1982 p. 220).

\begin{tabular}{|c|r|r|r|r|r|}
\hline & \multicolumn{1}{|c|}{1931.} & \multicolumn{1}{c|}{1948.} & \multicolumn{1}{c|}{1953.} & \multicolumn{1}{c|}{1961.} & \multicolumn{1}{c|}{1971.} \\
\hline WOMEN & $93,9 \%$ & $78,4 \%$ & $72,1 \%$ & $58,4 \%$ & $43,5 \%$ \\
\hline MEN & $74,5 \%$ & $46,9 \%$ & $39 \%$ & $29,8 \%$ & $21,3 \%$ \\
\hline IN TOTAL & $84,2 \%$ & $62,5 \%$ & $54,8 \%$ & $41,1 \%$ & $32 \%$ \\
\hline \hline
\end{tabular}

TABLE 1: ILLITERACY RATE IN Kosovo AND MEtoHIJA BETWEEN 1931 AND 1971

\section{THE ISSUE OF INTERETHNIC RELATIONS}

The majority of Albanian teachers in Kosovo and Metohija participated in the educational system of the "Kingdom of Albania" during the war, which hampered the new socialist regime's educational plans. The process of modernisation and cultural development in socialist Yugoslavia was under the strict control of the party apparatus and security services, in charge of preventing the penetration of 'bourgeois elements', nationalism, and cultural influences from the West and the Soviet Union. The security services were unhappy with the state of education in Kosovo and Metohija, underlining that teachers are the primary instigators of nationalism and hatred in society. From 1945 until 1962, 64 teachers in the Prizren district were prosecuted for coordinating hostile actions, and a similar scenario existed in other districts of Kosovo and Metohija. ${ }^{31}$

29 AJ, 318, f. 24, 'Izveštaj o radu Saveta za prosvetu AKMO za 1961', December, 1961, 19; AJ, 318, f. 94, a.j. 127. 'Osnovno obrazovanje odraslih', 1963.

30 The patriarchal attitude on women's role was also present in other European communist countries (Jarska, 2019, pp. 469-483) 
Although post-war legal acts guaranteed the right to education in the mother tongue to all national minorities, in Kosovo and Metohija this right was enjoyed exclusively by Albanians. The party's Albanian officials stated that there were no Turks in Kosovo and Metohija, but that they were Albanians who had absorbed the Turkish language and customs during their centuries in the Ottoman Empire. Turkish children were enrolled in Albanian classes, which made it difficult for them to communicate with teachers (Vidačić, 2000, pp. 179-180; Elmas, 2014, pp. 136-137).

After the conflict with the Soviet Union in 1948, Tito's Yugoslavia turned to cooperation with the hitherto hostile, capitalist Balkan countries - Turkey and Greece. This resulted in the recognition of the Turkish national minority in the Autonomous Region of Kosovo and Metohija. In 1951, classes in Turkish for students of Turkish nationality began in primary and secondary schools.

\begin{tabular}{|r|r|r|r|r|}
\hline & \multicolumn{1}{|c|}{$\begin{array}{c}\text { SERBIAN } \\
\text { LANGUAGE }\end{array}$} & \multicolumn{1}{|c|}{$\begin{array}{l}\text { ALBANIAN } \\
\text { LANGUAGE }\end{array}$} & \multicolumn{1}{c|}{$\begin{array}{l}\text { TURKISH } \\
\text { LANGUAGE }\end{array}$} & IN TOTAL \\
\hline $1945 / 1946$. & 27.211 & 23.536 & - & 50.747 \\
\hline $1956 / 1957$. & 40.224 & 78.395 & 2.472 & 122.091 \\
\hline $1965 / 1966$. & 67.719 & 131.607 & 3.188 & 202.514 \\
\hline $1969 / 1970$. & 66.059 & 163.821 & 2.532 & 232.412 \\
\hline \hline
\end{tabular}

TABLE 2: NUMBER OF PRIMARY SCHOOl STUDENTS IN KOSOVO AND METOHIJA, ACCORDING TO THE LANGUAGE OF STUDY, BETWEEN 1945 AND 1970.

The news of the opening of Turkish schools was met with resentment among Albanian teachers. According to a security report, in the mid-1950s, a struggle between Albanian and Turkish schools persisted in Kosovska Mitrovica, with Albanian educators campaigning against pupils enrolling in Turkish schools. ${ }^{32}$

The government's efforts to promote multiethnic harmony in Kosovo and Metohija had very modest results. At a grammar school in Pristina during the 1950s, Albanian and Serbian teachers did not communicate with each other. The school was strictly divided

31 AS, BIA, III-136, Izveštaj o neprijateljskoj delatnosti i antisocijalističkim pojavama u sredinama prosvetnih radnika, srednjoškolske i studentske omladine na Kosmetu, 2

32 Arhiv Srbije [Archives of Serbia] (AS), fond Bezbednosno-informativne agencije [Archive group of the Security Information Agency] (BIA), III-136, 'Stanje albanskog prosvetnog kadra na terenu AKMO', 1962, 5. 
according to the ethnic criteria ('Serbian floors' and 'Albanian floors'), while fights often broke out among students on ethnic basis. There were frequent boycotts of classes taught by professors of different nationalities. Authorities largely swept interethnic incidents under the rug, which did not help solve the problem. ${ }^{33}$

One of the characteristics of schooling in Kosovo and Metohija in the first post-war decade was the physical separation of schools for Serbian, Albanian and Turkish students. In the early fifties, the educational authorities began to think about merging schools of different nationalities into the same school buildings. The final decision was made in 1955 when it was concluded that 'in a socialist country there should be no Serbian, Albanian or Turkish school, but only a socialist school'. It was also determined that the separation of schools leads to national closure and intolerance. ${ }^{34}$ In the following school year for the first time, in addition to Serbian, Albanian, and Turkish schools in Kosovo and Metohija, mixed schools began to operate, which were attended by students of different nationalities. ${ }^{35}$ Minority rights were maintained in these schools, as students were distributed according to their native language in classes. However, some Albanian organisations, such as the Association of Albanian Students in Belgrade, resented the change, seeing in it a danger of assimilation. ${ }^{36}$

A special challenge for the authorities was the subject of history. In the first post-war years, Albanian students in Yugoslavia used textbooks printed in Albania, written according to this country's curriculum. Following the conflict between Belgrade and Tirana in 1948 the subject of history for national minorities in Kosovo and Metohija became identical to this subject for Serbian students. This created dissatisfaction among Albanian parents, students, and teachers, who generally did not teach the subject following the official state program. As an attempt to promote national reconciliation, in 1957 a unique history curriculum was introduced for all

33 AS, BIA, III-136, 'Stanje albanskog prosvetnog kadra na terenu AKMO', 1962, 5.

34 AJ, 507, XVIII-K.6/17, 'Aktuelni problem škola nacionalnih manjina i reforma škola - referat', Apr. 1957.

35 AJ, 507, XVIII-K.6/11, 'Izveštaj o razvoju i problemima manjinskog školstva u Jugoslaviji 1945-1956’, 1956, 17.

36 AJ, 142, SSRNJ [Socialist Alliance of Working People of Yugoslavia], f. 101, a.j. 782, 'Izveštaj Komisije SSRNJ: Aktuelni problemi nacionalnih manjina u Srbiji', 11 Apr. 1959. 
students in Kosovo and Metohija, which, in addition to Serbian, also included material from Turkish and Albanian history. ${ }^{37}$

Since 1957, Serbian students in Kosovo and Metohija were given the opportunity to study Albanian language as an elective school subject. The overwhelming majority of Serbian students chose to study Albanian, which enabled them to interact in ethnically mixed areas more easily (Bondžić, 2008, pp. 88-97). ${ }^{38}$ However, Albanian teachers were dissatisfied with the fact that Serbian was a compulsory subject for Albanian students, while Albanian was taught as an elective in Serbian classes. The most common form of Albanian nationalism among students and teachers in Kosovo-Metohija schools during socialism was a call for a boycott of Serbian language teaching. A 1962 report by the security services to the State Secretariat for the Interior stated that in some schools, Serbian teachers were being pressured to leave some jobs, while others were preparing to do the same. ${ }^{39}$

THE SOCIAL AND MATERIAL ASPECT OF EDUCATION

In addition to the incompetence of the educational staff, the problem was the irresponsibility of many teachers, who were frequently absent for several months, and replacements were not hired. A 1956 report on the state of education by the Security Service stated that educators did not enjoy a sufficient reputation in Priština and the surrounding areas, because they were generally poorly educated and did not behave in accordance with the standards of their profession. ${ }^{40}$

Marxist ideas in education have were not realized in the field of the attitude of educators and students towards religion neither. Reducing the influence of traditional religions was considered one of the main goals of Eastern European communist regimes in in the field of cultural policy (Tóth, 2020, pp. 174-177; Smolkin, 2018;

37 AJ, 507, XVIII-K.9/18, 'Pregled nekih nedovoljno objašnjenih društveno-političkih pitanja i specifičnosti nastavnih programa i pedagoškog rada u školama za pripadnike nacionalnih manjina', 8 Jan. 1959.

38 AJ, 507, XVIII-K.9/22, 'Kulturno-prosvetni problem nacionalnih manjina', 1959, 7.

39 AS, BIA, III-136, Izveštaj o neprijateljskoj delatnosti i antisocijalističkim pojavama u sredinama prosvetnih radnika, srednjoškolske i studentske omladine na Kosmetu, 12-13.

40 AS, BIA, III-121, 'Referat o nacionalnim manjinama, Izveštaj UDB Priština', 16 Mar. 1956, 4. 
Radić, Mitrović, 2012, pp. 688-706, 721-725). However, the deficiency of teachers forced the Communist Party to partially abandon the repressive religious policy. A number of teachers were employed with a completed madrasa (Islamic religious school), or with only a several grades of a madrasa completed. The educators, who came from the families of khawaja's, beys, and merchants, were mostly religious and devoted to tradition. In many places, students fasted during Ramadan, did not come to school on religious holidays and some teachers actively participated in the practice of Islam. In 1956, there were cases of teachers performing religious rites and prayers in front of children in classrooms. ${ }^{41}$ During major religious holidays, some schools did not work at all. Although polygamy was prohibited under Yugoslav law, teachers had two wives in some traditional Kosovo communities. ${ }^{42}$ Many parents did not enroll their female children in school, in line with the patriarchal outlook on life. Those whose daughters attended school were looking for the first excuse to drop them off. This resulted in a low percentage of female students who managed to complete eight years of primary school. Out of 463 female students enrolled in the first grade of primary school in Vučitrn, only 41 managed to finish eight years of school. The situation in rural areas was even more difficult. ${ }^{43}$

Schools in Kosovo and Metohija faced the issue of poverty like other schools in Yugoslavia. School budgets were small and barely covered basic personal expenses. Reports from the School and Science Committee testify that Kosovo and Metohija schools lacked maps, abacus, and other teaching subjects. The number of textbooks for schools was also inadequate..$^{44}$ One of the negative factors in the development of schooling was the lack of school space. In the early 1950s an average of 75 students came to one classroom in Kosovo, while classrooms in other parts of Serbia and Yugoslavia were generally less congested. In Croatia, an average of 62.5 students came to one classroom, and in central Serbia 61.2 students. Some city schools in Kosovo worked in three or even four shifts a

41 AS, BIA, III-121, Izveštaj UDB Priština - Nacionalna manjina i IB-e zemlje, 16 Mar. 1956, 4.

42 AS, BIA, III-136, Izveštaj o neprijateljskoj delatnosti i antisocijalističkim pojavama u sredinama prosvetnih radnika, srednjoškolske i studentske omladine na Kosmetu, 29 Jan. 1962, 14.

43 AJ, 507, XVIII-K.7/5, 'Osipanje učenika u osnovnim školama', 1958, 5.

44 AJ, 315, f. 11, 'Izveštaj Ministarstva prosvete Srbije Komitetu za škole i nauku u Vladi FNRJ', 27 Mar. 1948. 
day. ${ }^{45}$ Many school buildings were built before the war and were not originally intended for educational purposes, but were subsequently adapted for it. In the interwar period, schools were sometimes opened in private houses, churches, mosques, and taverns, and this practice continued in the first post-war years (Narodni odbor Autonomne kosovsko-metohjske oblasti 1943-1953, 1953, p. 747; Slavković, 2018, p. 467). On 6 September 1945 the Kosovo and Metohija Department of Education sought money from the Land Reconstruction Fund to erect new and repair damaged school buildings. ${ }^{46}$

On 25 August 1952, Osman Peroli, a member of the Regional Executive Council, stated that the material problem of schooling stemmed from the fact that the expansion of the school network after the war was not accompanied by a solution to the problem of school space. According to him, out of 703 school buildings in Kosovo and Metohija, more than half did not meet basic pedagogical and hygienic requirements.

Finally, in 1957 the Regional People's Assembly of Kosovo and Metohija adopted a Decision on the conditions for the construction of school buildings, which was based on modern educational standards. The report of the Commission for Education, which preceded the adoption of the Decision, concluded that it was necessary to abandon the old approach according to which it was enough to design classrooms and administration offices for the construction of a school building. The commission stated that none of the 506 school buildings built in Kosovo and Metohija in the previous 35 years met modern pedagogical requirements, and that most of them did not even meet basic construction standards. It was declared that there should be greater cooperation between architects and pedagogues in the future during the construction of school buildings. By the decision of the People's Assembly of Kosovo and Metohija from 1957, the erection of school buildings was prohibited unless the Commission of the Education Council had previously assessed that the project was in accordance with mod-

45 The situation with the school space was more difficult only in Bosnia and Herzegovina, where an average of 92.6 students came to one classroom. See: AJ, 318, f. 12, a.j. 16, Rukovođenje školstvom.

46 AJ, 41, Savezna planska komisija [Federal Planning Commission], f. 21, Pismo poverenika za prosvetu Oblasnog narodnog odbora Kosova i Metohije ministru industrije u Vladi FNRJ Andriji Hebrangu, 6 Sept. 1945. 
ern urban principles and pedagogical demands. (Narodni odbor Autonomne kosovsko-metohijske oblasti 1956-1957, 1961, pp. 705-707).

Teacher incompetence, cultural backwardness of the community, and lack of material conditions influenced Kosovo and Metohija to be the Serbian region with the lowest primary school completion rate. The decrease in the number of students had begun already in the first grade, so that out of 42,467 students who enrolled in the first grade of the school year 1946/1947, only 19,581 enrolled in the second grade. The problem of students dropping out of school was not solved in the following decade, so that out of 52,017 students enrolled in the first grade in 1955, only 17.1 per cent managed to enroll in the fourth grade in $1958 .{ }^{47}$

\section{DEVELOPMENT OF SECONDARY AND HIGHER EDUCATION}

With the introduction of seven years of elementary education in 1945 , only the former upper grammar schools were retained at the second level of education. Initially, four cities in Kosovo and Metohija had secondary schools-Priština, Prizren, Peć, and Đakovica. This changed during the 1950s when secondary schools were opened in all municipal centers. 48

In line with the increased need for skilled workers after the Second World War, there was an expansion of vocational schools, in which students were trained to work in the industry. Unlike grammar schools, teaching in vocational schools was based on a combination of practice and theory, and students spent much of their time in workshops and factory facilities (Alix, 2019, pp. 479-495). Vocational schools were divided into three-year and four-year schools. In some three-year industrial schools, students acquired knowledge through practical work in manufactories and craft workshops, for which they were receiving financial compensation. In other three-year schools manual training classes took place in school workshops, following the school plan and under the supervision of teachers. ${ }^{49}$

The development of vocational schools in Kosovo and Metohija had lagged behind the rest of Serbia. During the school year of 1962/1963, 29,045 students in Serbia attended schools for students

47 AJ, 507, XVIII-K.7/5, Osipanje učenika u osnovnim školama, 1958, 2-3.

48 AJ, 315, f. 3, a.j. 895, 'Ministarstvo prosvete Srbije Komitetu za škole i nauku FNRJ', 27 Mar. 1947.

49 AJ, 318, f. 41, a.j. 66, 'Izveštaji o problemima stručnog školstva 1953-1963’. 
in economics, of whom only 2,001 were students in Kosovo and Metohija. ${ }^{50}$ An important factor in the underdevelopment of the secondary school network in Kosovo was the non-existence of teaching in the Albanian language. That was a significant difference compared to primary schools, where classes in the mother tongue were guaranteed to all Albanians and Turks. While the number of Albanian students in Kosovo's primary schools in 1961 was 70 per cent higher than the number of Serbian students, Serbs made up more than half of the students in secondary schools. The main reason for not enrolling Albanians in secondary schools was their inability to attend classes in Serbian language. ${ }^{51}$

Secondary schools in the Serbian language were enrolled by ambitious Albanian students, who intended to enroll in some of Belgrade's faculties. For that reason, the philosopher and politician Shkëlzen Maliqi started attending classes in the Serbian language from the fifth grade of primary school (Malići, 2014, p. 62).

The lack of Albanian workers resulted in a low proportion of Albanians in the employment structure, which the provincial leadership used as evidence of "national discrimination”. ${ }^{22}$ Since 1959, a campaign was launched to introduce minority language teaching in secondary vocational schools. The Council for Education of Kosovo and Metohija explained the introduction of teaching in the Albanian language in secondary schools by the need to increase the professional staff in companies and the state administration. ${ }^{53}$

The interest of primary school graduates in pursuing their education grew during the 1960s, but the secondary school network in the region remained underdeveloped relative to the rest of Yugoslavia. ${ }^{54}$ The main goal of the provincial leadership in that period

50 AJ, 318, f. 51, a.j. 66, 'Statistička dokumentacija. Učenici u privredi na početku 1962/1963. godine’, Mar. 1963, 1-4.

51 AJ, 318, f. 43, a.j. 58. 'Pismo predsednika Odbora za prosvetu Narodnog sobranja Makedonije Dimče Mirea Saveznom sekretarijatu za obrazovanje i kulturu', 8. Jan. 1959.

52 AS, Izvršni komitet [Executive Committee], f. 2, 'Stenografske beleške sa proširene sednice Izvršnog komiteta CK SK Srbije’, 27 Jan. 1959, 98.

53 AJ, 318, f. 43, a.j. 58, 'Mišljenje i primedbe Saveta za prosvetu AKMO na materijal Saveznog sekretarijata za obrazovanje o školama nacionalnih manjina', 31 Jan. $1959,4$.

54 AJ, 837, Kabinet Predsednika Republike [Cabinet of the President of the Republic], II-5-c-2/203, Materijali pokrajinskog izvršnog veća, a.j. 8, 'Akcioni program za razrešavanje aktuelnih problema obrazovanja AP KiM', 31 Dec. 1968, 16-19. 
was to expand the network of higher education institutions, while the issue of secondary schools remained in the background.

The oldest higher education institution in Kosovo and Metohija was the Higher Pedagogical School in Pristina, opened in 1958 (VI oblasna konferencija Socijalističkog saveza radnog naroda Srbije za Kosovo $i$ Metohiju, 1961, p. 38). The proposal for its establishment was sent in 1955, after the Serbian authorities were persuaded that the proportion of educated teachers in Kosovo was insufficient. Only 2.8 per cent of teachers in primary schools in Kosovo had completed the Higher Pedagogical School, while at the level of Serbia, 63 per cent of teachers had a diploma of this school. The Federal Secretariat for Education and Culture had taken the position that after Belgrade, Kragujevac, Zrenjanin, and Niš, the fifth city in Serbia with the Higher Pedagogical School should be Priština. ${ }^{55}$

The statement of the President of the Executive Council of Kosovo and Metohija Fadil Hoxha from 1959 testifies to how enthusiastically the provincial authorities viewed the issue of higher education and young intellectuals: "We can't wait for a man to come from the faculty to be appointed as a mayor or high-ranking manager. These are the brightest people who can understand the whole process more easily." 56

After the opening of the Higher Pedagogical School, the network of higher education schools began to expand rapidly. The Higher School of Administration in Priština, the Higher School of Economics, Higher Commerce School in Peć, and the Higher School of Agriculture in Priština were soon established. The oldest faculty was the Faculty of Philosophy, which was founded in 1960 (VI oblasna konferencija Socijalističkog saveza radnog naroda Srbije za Kosovo i Metohiju, 1961, p. 38; Vukadinović, 2008, p. 52). The Faculty of Law and Economics was opened in Priština the next year, and the Faculty of Engineering was established in 1965 . Until then, over 6,000 students studied in the province..$^{57}$

55 AJ, 318, f. 51, a.j. 66, 'Škole za obrazovanje nastavnika za obavezno školovanje', 5-6.

56 AS, Izvršni komitet, f. 2. 'Stenografske beleške sa proširene sednice Izvršnog komiteta CK SK Srbije', 27 Jan. 1959, 98.

57 AS, Savez komunista Kosova [Archive group of the League of Communists of Kosovo], f. 3, 'Sednica Sekretarijata Pokrajinskog komiteta Saveza komunista Srbije za Kosovo i Metohiju, Informacija o nekim akutelnim pitanjima na višim školama i fakultetima', 10 Jan. 1966. 
Based on the completion rate of secondary schools and the dynamics of growth in the number of university students, the authorities in 1966 predicted that 11,560 students would attend faculties in the Autonomous Province of Kosovo and Metohija by 1969. However, this target was reached already in $1968 . .^{58}$ The network of faculties in Kosovo and Metohija was an integral part of the University of Belgrade (Vukadinović, 2008, p. 52). According to the Kosovo Bureau of Statistics, more Albanians graduated between 1968 and 1970 than between 1961 and 1967 (Privredni i društveni razvoj SAP Kosova 1947-1972, 1974, p. 129; Nuši, 1977, p. 20). The appearance of Priština as a student city was unexpected for many of the city residents. In 1963, the Priština journalist, Miodrag Nikolić wrote that "nobody could have predicted that a university town would grow out of Priština, the former Ottoman provincial town" (Nikolić, 1963, p. 47).

Problems that emerged in primary and secondary schools in Kosovo and Metohija were also present in higher schools and faculties. They began to work without an adequate number of qualified teachers, without a developed curriculum and regulated organisational issues. This led to the employment of insufficient quality teachers, as well as the formation of 'national clans' in the teaching staff, who fought each other for positions. When the teaching-scientific councils were deciding on the employment of new professors, the ethnicity of the candidates often took precedence over their academic credentials and expertise. ${ }^{59}$

The unresolved interethnic and economic problems of higher education escalated on November 27, 1968, with the mass student demonstrations in Priština. Albanian students chanted to Tito, but at the same time demanded the separation from Serbia and the creation of the 'Republic of Kosovo'. They also demanded the separation of the Priština faculties from the University of Belgrade and the establishment of the University of Priština (Gatalović, 2018, pp. 165-166; Lalaj, 2018, pp. 246-247). Although great material damage was caused and one person was killed in the violent protests, none of the professors who participated in the organisation of the demonstrations suffered the consequences. The Yugoslav leader-

58 AJ, 837, II-5-c-2/203, 'Akcioni program za razrešavanje aktuelnih problema obrazovanja i culture AP KIM', 12 Oct. 1968.

59 AS, BIA, III-136, 'Izveštaj o neprijateljskoj delatnosti i antisocijalističkim pojavama u sredinama prosvetnih radnika, srednjoškolske i studentske omladine na Kosovu', 29 Jan. 1962, 17-18. 
ship ordered that this event be covered up by the media. Josip Broz said that students were demonstrating in the West as well, and that there is no reason to 'dramatise' the situation in Kosovo (Mišović, 1987, p. 213; Bataković, 2012, pp. 110-112). The Communist Party decided to accept most of the protesters' demands, so on November 18, 1969 the Assembly of the Socialist Autonomous Province of Kosovo passed the Law on the Establishment of the University of Priština, which included all the faculties in Kosovo (Vukadinović, 2008 , p. 52). In the same year, the first agreements of cooperation were signed with the University of Tirana, so that in the following years, professors from Albania were hired as lecturers at the University of Priština. ${ }^{60}$

CONCLUSION From the commencement of Kosovo and Metohija's autonomy, the issue of education held a unique place. Upon the intervention of the regional communist leadership, the state allocated significant financial resources for the expansion of the school network, as well as other institutions that had the function of cultural upliftment of the population. Political engagement and material investments in this sphere went ahead of human capacities for the expansion of education so that people without the necessary qualifications also worked as teachers. As a result, the efficiency of schooling was significantly lower than in the rest of Yugoslavia. However, by the end of the 1960s, illiteracy had been halved and reduced to 32 per cent, while over 95 per cent of children were covered by primary education. As many as four cities in Kosovo and Metohija formed higher education institutions, which was not the case in any other region of Serbia. Within two and a half decades, the educational transformation of the Kosovo and Metohija society was carried out.

Proclaimed goals of Yugoslav educational policy regarding inter-ethnic reconciliation and the creation of a multicultural society were not realized. In order to achieve better results in the field of quantitative indicators of education development-the number of schools, professors and highly educated people-the authorities made numerous compromises regarding the quality, but also the ideological characteristics of the educators. In the absence of qualified teachers, the authorities hired teachers with highly nationalistic views at work, as well as those who were outspoken opponents

60 AQSH, f. 511, v. 1969, d. 19, Përkujtesë në lidhje me gjallërimin e veprimtarisë shkencore-kulturale në Kosovë dhe me qëndrimin tonë ndaj saj, n.a. 6-8. 
of the existing political order. In the long run, this activity harmed the communist government's reputation, turning schools into a breeding ground for the manifestations of nationalism and interethnic conflicts. 
Arhiv Jugoslavije [Archives of Yugoslavia], Belgrade

- 41, Savezna planska komisija [Archive group of the Federal Planning Commission]

- 97, Komisija za agrarnu reform i kolonizaciju pri Vladi FNRJ [Commission for Agrarian Reform and Colonization of the Government of the Federal People's Republic of Yugoslavia]

- 142 , Socijalistički savez radnog naroda Jugoslavije [Socialist Alliance of Working People of Yugoslavia]

- 313, Ministarstvo prosvete Vlade FNRJ [Ministry of Education of Yugoslavia]

- $\quad 315$, Komitet za škole i nauku pri vladi FNRJ [Committee for Schools and Science under the Government of the Federal People's Republic of Yugoslavia]

- 318, Savezni sekretarijat za obrazovanje i kulturu [Federal Secretariat for Education and Culture]

- 319, Savezni savet za obrazovanje i kulturu [Federal Council for Education and Culture]

- $\quad 507$, Centralni komitet Saveza komunista Jugoslavije [Central Committee of the League of Communists of Yugoslavia]

- 837, Kabinet Predsednika Republike [Cabinet of the President of the Republic]

Arhiv Srbije [Archives of Serbia], Belgrade

- Bezbednosno-informativna agencija [Security Information Agency]

- Savez komunista Kosova [League of Communists of Kosovo]

- Izvršni komitet [Executive Committee]

Diplomatski arhiv Ministarstva spoljnih poslova Srbije [Diplomatic archive of the Ministry of Foreign Affairs of Serbia], Belgrade

- Politička arhiva [Political archive]

Arkivi Qendror Shtetëror [Central state archives of Albania], Tirana

- 178, Ministria e Financave, Drejtoria e Pergjithshme e Financave [Ministry of Finance, General Directorate of Finance]

- 511, Ministria e Arsimit dhe Kulturës [Ministry of Education and Culture] 
REFERENCES V kongres Komunističke partije Jugoslavije. Izveštaji i referati (1948). Beograd: Kultura.

VI oblasna konferencija Socijalističkog saveza radnog naroda Srbije za Kosovo $i$ Metohiju (1961). Pristina: Oblasni odbor SSRNS za Kosovo i Metohiju.

Alix, S. (2019). The hand as agent of the mind? The irony of manual training reform in Menomonie, Wisconsin (1890-1920). History of Education, 48 (4), 479-495.

Bataković D. (2012). Serbia's Kosovo Drama. A Historical perspective, Belgrade: Čigoja.

Bondžić, D. (2008). Jedan dokument o dvojezičnom školstvu na Kosovu i Metohiji 1961. godine. Arhiv, (1-2), 88-97.

Bondžić, D. (2010). Opismenjavanje u Jugoslaviji i Srbiji u periodu 1945-1950: nasleđe, ciljevi, tok, rezultati i nedostaci. Andragoške studije, (1), 91-110.

Craig, J. (1981). The Expansion of Education. Review of Research in Education, $9(1), 151-213$.

Dimić, Lj. (1988). Agitprop kultura. Agitpropovska faza kulturne politike u Srbiji. Belgrade: Rad.

Dimić, Lj. (1990). Prosvetna politika Kraljevine Jugoslavije na Kosovu i Metohiji 1918-1941. i istoriografija. Istorija 20. veka, (1-2), 189-196.

Dobrivojević, I. (2011). Obrazovanje u službi ideologije - Prosvetni napori vlasti na srpskom selu 1945-1955. Istorija 20. veka, (3), 157-170.

Doknić, B. (2013). Kulturna politika Jugoslavije 1946-1963. Belgrade: Službeni glasnik.

Elmas, N. (2014). Kosovalı Türkler: Dilleri ve Kültürleri. Bilig, 70, 131-152.

Fetahu, A., Çunaku, M. (2011) Kujtimi për një Gjeneratë. Monografi për Nxënësit e Shkollës Normale të Prishtinës, Gjenerata 1956-1961. Pristina: TREND.

Gatalović, M. (2018). Burna vremena. Kosovo i Metohija u državnoj politici Jugoslavije 1966-1969. Beograd: Institut za savremenu istoriju.

Gatalović, M. (2009). Između ideologije i stvarnosti: Socijalistički koncept kulturne politike Komunističke partije Jugoslavije 1945-1960. Istorija 20. ve$k a, 27$ (1), 37-56.

Gudac-Dodić, V. (2006). Školovanje žena u Srbiji (1945-1991). Tokovi istorije, (3), 90-104.

Islami, H. (1982). Nepismenost u današnjem kosovskom selu. Sociologija sela, 20 (77/78), Zagreb, 219-232.

Lalaj, A. (2018). Ngjashmëri dhe pangjashmëri në lëvizjes e 1968-s. Studime Historike, (3-4), 237-259. 
Malići, Š. (2014). Kosovo i raspad Jugoslavije. Belgrade: Radnička komuna Links.

Miladinović, M. (1977). Tito o socijalističkom vaspitavanju omladine. Priština: Pokrajinski centar za marksističko obrazovanje.

Mišović, M. (1987). Ko je tražio republiku. Kosovo 1945-1985. Belgrade: Narodna knjiga.

Nikolić, M. (1963). Kosovo i Metohija. Pregled društveno-ekonomskog razvitka. Beograd: Sedma sila.

Narodni odbor Autonomne kosovsko-metohjske oblasti 1943-1953 (1955). Pristina: Narodni odbor Autonomne kosovsko-metohijske oblasti.

Narodni odbor Autonomne kosovsko-metohijske oblasti 1956-1957 (1961). Pristina: Narodni odbor Autonomne kosovsko-metohijske oblasti.

Jarska, N. (2019). Female Breadwinners in State Socialism: The Value of Women's Work for Wages in Post-Stalinist Poland. Contemporary European History, 28 (4), 469-83.

Nuši, P. (1977). Saradnja Univerziteta u Prištini i Univerziteta u Tirani. Pristina: Pokrajinski centar za marksističko obrazovanje "Ideje i akcije".

Privredni i društveni razvoj SAP Kosova 1947-1972 (1974). Pristina: Pokrajinski zavod za statistiku.

Petrović-Todosijević, S. (2016). Socijalizam u školskoj klupi. Reforma osnovnoškolskog sistema u Srbiji (1944-1959). Doctoral dissertation, Singidunum University, Faculty of Media and Communications.

Radić, R., Mitrović, M. (2012). Zapisnici sa sednica Komisije za verska pitanja NR/SR Srbije 1945-1978. godine. Beograd: Institut za noviju istoriju Srbije.

Slavković, B. (2018). Političke, ekonomske i kulturne prilike na Kosovu i Metohiji 1929-1941. Belgrade: Princip.

Smolkin, V. (2018). A Sacred Space is Never Empty: A History of Soviet Atheism. Princeton: Princeton University Press.

Tóth, H. (2020). Dialogue as a Strategy of Struggle: Religious Politics in East Germany, 1957-1968. Contemporary European History, 29, 171-186.

Vidačić, R. (2000). o korenima separatizma i terorizma na Kosovu. Belgrade: Službeni glasnik.

Vukadinović, I. (2020). Prosvetna politika Kraljevine Albanije na Kosovu i Metohiji tokom Drugog svetskog rata. Tokovi istorije, (1), 109-132.

Vukadinović, Z. (2008). Prištinski univerzitet i njegove biblioteke. Savremena biblioteka, 25, 51-54. 
ИГОР Ђ. ВУКАДИНОВИТ

БАЛКАНОЛОШКИ ИНСТИТУТ САНУ

БЕОГРАД

РЕЗИМЕ

СОЦИЈАЛИСТИЧКА ПРОСВЕТНА ПОЛИТИКА У АУТОНОМНОЈ КОСОВСКО-МЕТОХИЈСКОЈ ОБЛАСТИ: ЦИЉЕВИ, ЗАДАЦИ И ИСХОДИ

Албански функционери у Комунистичкој партијији Југославије Фадиљ Хоџа и Зекерија Реџа су питање образовања успели да наметну као једно од државних приоритета на простору Косова и Метохије у првим послератним годинама. Први задатак био је задржавање албанских учитеља доведених из Албаније током окупације као и довођење нових учитеља из ове земље, на чему је било ангажовано Председништво АВНОЈ-а, министарство спољних послова, министарство просвете и Комитет за школе и науку Федеративне Народне Републике Југославије. обласне власти Косова и Метохије су се за материјалну помоћ у изградњи школског простора директно обраћале и министру индустрије ФНРЈ и председнику Савезне планске комисије Андрији Хебрангу. Док су течајеви за описмењавање одраслих превасходно су имали пропагандну улогу, ширење школске мреже дало је видљиве резултате тако да је до средине педесетих година број ученика у основним школама удвостручен. Развој високих школа и факултета у области крајем педесетих година заснивао се на сличном приступу који је примењен у ширењу основног школства. Потреба повећања броја факултетски образованих људи у што краћем року потиснула је квалитет школовања у други план. Упркос званичној реторици и прокламованим циљевима, просветна политика социјалистичке Југославије није довела до смањивања, него до раста међунационалних тензија на Косову и Метохији. Уз изражену националну подвојеност и бројне инциденте, школе у области су предствљале полигоне за испољавање националие нетрпељивости.

КљУчнЕ РЕчи: просвета, образовање, социјализам, Савез комуниста Југославије, Косово и Метохија, писменост.

Овај чланак је објављен и дистрибуира се под лиценцом Creative Commons

Ауторство-Некомерцијално Међународна 4.0 (СC BY-NC 4.0 |

https://creativecommons.org/licenses/by-nc/4.0/).

This paper is published and distributed under the terms and conditions of the Creative Commons Attribution-NonCommercial International 4.0 licence (CC BY-NC 4.0 | https://creativecommons.org/licenses/by-nc/4.0/). 